Marek Świerczyński *

Bartłomiej Oręziak **:

\title{
JUDGMENT OF THE COURT (SECOND CHAMBER) OF 27 SEPTEMBER 2017 IN JOINED CASES C-24/16 AND C-25/16 IN THE PROCEEDINGS NINTENDO CO. LTD V. BIGBEN INTERACTIVE GMBH, BIGBEN INTERACTIVE SA
}

Keywords

Community design rights - Court of Justice of the European Union - Nintendo v. BigBen

\section{Preliminary Remaris}

The judgment of 27 September 2017 of the Court of Justice of the European Union (CJEU)'s in the case of Nintendo v. BigBen ${ }^{1}$ provides important conclusions concerning the determination of the law applicable to the consequences of infringement of Community design right. It is based both on Article 8 of Regulation (EC) No. 864/2007 of the European

* Dr hab. Marek Świerczyński, prof. UKSW, Faculty of Law and Administration, Cardinal Wyszyński University in Warsaw; m.swierczynski@uksw.edu.pl.

** Bartłomiej Oręziak, M.A., Doctoral candidate, Faculty of Law and Administration, Cardinal Wyszyński University in Warsaw; boreziak@gmail.com.

${ }^{1}$ Nintendo Co. Ltd $v$. BigBen Interactive GmbH, BigBen Interactiv SA, Joined Case C 24/16 and C 25/16, Judgment of 27 September 2017, E.C.R 2017, (ECLI:EU:C:2017:724). 
Parliament and of the Council of 11 July 2007 on the law applicable to non-contractual obligations (Rome II) ${ }^{2}$ and relevant EU Regulations of Community design right ${ }^{3}$. CJEU clearly explained: 1) what are the connections of the above-mentioned provisions, and 2) what is the proper qualification of a connecting factor based on the infringement of Community design right.

Disputes regarding infringements of Community design rights are characterized by their particular complexity ${ }^{4}$. Often the same defendant is accused of several infringing acts. Infringement of one EU right (here Community design right) extends over more than one Member State. This situation results in the problem of whether one single law should be applied then, or a "mosaic" of different laws. In result many circumstances of the complex factual situation can be considered as a connecting factor important for determination of the applicable law. It is also possible that these factors may indicate several legal systems as potentially applicable ${ }^{5}$.

2 Official Journal UE L 199, 31 July 2007, p. 40-49; In the Polish literature see: A. Nowicka, Prawo właściwe dla zobowiązań wynikających z czynów niedozwolonych w świetle przepisów rozporzadzenia nr 864/2007 [Law Applicable to Obligations Arising from Tortious Acts Under the Provisions of Regulation No. 864/2007], [in:] J. Barta, A. Matlak (ed.), Prawo własności intelektualnej. Wczoraj, dziś i jutro [Intellectual Property Law. Yesterday, Today And Tomorrow], "Zeszyty Naukowe Uniwersytetu Jagiellońskiego" [ZNUJ] 2007, vol. 100, pp. 311-335; A. Nowicka, Kolizyjnoprawna problematyka prawa własności przemystowej [Conflict-of-law Problems in Industrial Property Law], [in:] R. Skubisz (ed.), Prawo własności przemystowej [Industrial Property Law], System Prawa Prywatnego [Private Law System], t. 14B, Warszawa: C. H. Beck, 2012, p. 1533; J. Szwaja, A. Kubiak-Cyrul, [in:] J. Szwaja (ed.) Ustawa o zwalczaniu nieuczciwej konkurencji. Komentarz [The Suppression of Unfair Competition Act. Commentary], Warszawa: C. H. Beck, 2017, p. 237.

${ }^{3}$ See: Council Regulation (EC) No. 6/2002 of 12 December 2001 on Community designs (O.J. L 3, 5.1.2002, p. 1-24) analyzed by CJEU in Nintendo v. BigBen case. When it comes to determining the applicable law, Regulation No 6/2002 provides in Article 88 that in all matters not falling within its scope, the Community design court applies the provisions of its national legislation, including its own private international law.

${ }^{4}$ What was pointed out before the adoption of Rome II Regulation by the EU; A. Lopez-Tarruella Martinez, IPR Helpdesk, The law applicable to intellectual property right infringements under the Proposal for a Regulation Rome II, no. 15, 2004, available on the site: http:/ /ipr-helpdesk.org/newsletter [last access: 25.6.2018].

5 This problem in private international law is not new, but creates special complications in the case of infringements of intellectual property rights; A. Mączyński, Wskazanie kilku praw przez norme kolizyjna prawa prywatnego międzynarodowego [Indication of Several 
For example, as analyzed in the Nintendo case, pursuant to Regulation No. $6 / 2002^{6}$, the Community design right grants the rights owner the exclusive right to use that design and to prohibit its use by other parties. Such use of industrial designs includes, in particular, the manufacture, offering, placing on the market, import, export, or use of a product based on the design. Moreover, uniform industrial property rights are protected throughout the EU territory. Infringement can therefore be made in the various Member States. As a result, determination of the applicable substantive law becomes highly unpredictable.

The above causes the risk that the national courts may adopt excessive, mosaic (scattered) methods for determining the applicable law. The judgment of the CJEU in the case of Nintendo v. BigBen tries to solve this problem. For the first time, CJEU opposed the mosaic method explicitly and proposed a consolidated approach, enabling the courts to choose one specific law as the governing law for the case. This approach is consistent with the proposals formulated so far in the doctrine. It departs from the excessively flexible solutions adopted by the courts with regard to national jurisdiction.

\section{FACTS}

Nintendo Co Ltd is a Japanese company that sells the "Wii" video game console. The "Wii" name is an EU trademark registered by Nintendo. The company is also the holder of several registered Community (EU) designs relating to Wii accessories, such as the Wii remote control, the accessory known as the "Nunchuck" for the Wii remote control, which enables compatible video games to be controlled differently, the connector plug known as the "Wii Motion Plus" for the remote control, and the

Legal Systems by the Conflict-of-law Rule in Private International Law], [in:] A. Mączyński, M. Pazdan, A. Szpunar (ed.), Rozprawy z polskiego i europejskiego prawa prywatnego: ksiega pamiątkowa ofiarowana profesorowi Józefowi Skapskiemu [Dissertations on Polish and European Private Law: Commemorative Book for Professor Józef Skąski], Kraków: Wydawnictwo i Drukarnia Secesja, 1994, p. 231-233.

${ }^{6}$ Supra note 3. 
Balance Board, an accessory that allows the player to control the game through weight changes.

Nintendo claimed that BigBen Interactive SA, the European leader in the production and distribution of video game accessories for smartphones and tablets, had violated the rights to the EU-registered designs of Nintendo. The infringement was based on the manufacture and sale of accessories that are compatible with Wii game consoles. The international element involved in the case is the sale of these accessories by a German affiliate, BigBen Interactive $\mathrm{GmbH}$, to buyers in Belgium, France, and Luxembourg.

Nintendo initiated court proceedings in Germany, demanding the discontinuation of the manufacture of products considered disputable, their import and export, and the prohibition of presenting or using the image of products based on protected EU designs.

In the first instance, the Landgericht Düsseldorf (Higher Regional Court in Düsseldorf, Germany) ruled, in its judgment, an infringement of the Nintendo IP rights related to the EU designs by subsidiaries BigBen based in France and Germany. The Court ordered them to stop using these designs. In the appeal proceedings, the higher court in Düsseldorf (Oberlandesgericht Düsseldorf) decided to suspend the proceedings and to refer questions to the CJEU for a preliminary ruling. One of these questions concerned the applicable law. That Court asked, inter alia, for the purposes of Article 8(2) of the Rome II Regulation7, how is the place "in which the act of infringement was committed" to be determined in cases in which the infringer: a) offers goods that infringe a Community design on a website and that website is also directed at Member States other than the one in which the person damaged by the infringement is domiciled, and/or; b) has goods that infringe a Community design shipped to a Member State other than the one in which it is domiciled". The Court asked also other questions. Namely, "(1) In connection with a trial to enforce claims under a Community design, can the court of a Member State whose jurisdiction with respect to a defendant is based solely on Article 79(1) of [Regulation No 6/2002] in conjunction with Article 6(1) of [Regulation No 44/2001], on the basis that this defendant,

\footnotetext{
7 Supra note 3.
} 
which is domiciled in another Member State, supplied the defendant domiciled in the pertinent Member State with goods that may infringe intellectual property rights, adopt measures against the first mentioned defendant that are applicable throughout the EU and extend beyond the supply relationships on which jurisdiction is based? (2) Is [Regulation No 6/2002], particularly Article 20(1)(c), to be interpreted as meaning that a third party may depict a Community design for commercial purposes if it intends to sell accessory items for the right holder's goods corresponding to the Community design? If so, what criteria apply to this?". This paper deals only with the problem of the applicable law.

\section{Opinion of the Advocate General Bot}

The conflict-of-law analysis presented in the Opinion of Advocate General Bot in the Nintendo v. BigBen case delivered on 1 March $2017^{8}$ is an excellent example of fault conflict-of-law analysis. At first, he divided Nintendo's claims, considering that it was required to determine the law applicable separately under Article 89 (1) (d) of Regulation No. 6/2002 and Article 8 (2) of the Rome II Regulation. In conclusion, he stated that under the terms of both these regulations, the applicable law is the same. Namely, this is the governing law on the territory of the Member State in which the event causing the infringement occurred or may occur and the incident causing the infringement is the production of counterfeit products.

The Advocate General presented an analysis of Article 89 (1) (d) of Regulation No. 6/2002. Owing to the fact that so far, the CJEU did not comment as to how to interpret the concept of "by the law of the Member State in which the acts of infringement or threatened infringement are committed, including its private international law", he considered, with regard to that provision, that the EU case-law on national jurisdiction should be used for this purpose.

${ }^{8}$ Opinion of Advocate General Yves Bot delivered on 1 March 2017 in Joined Case C 24/16 and C 25/16. 
He referred to the judgment of Coty Germany ${ }^{9}$, in which the CJEU pointed out that the concept of "the Member State in which the acts of infringement" suggests that this connecting factor refers to the active behaviour of the perpetrator of the infringement. The connecting factor provided for in this provision therefore applies to the territory of the Member State in which the event causing the infringement has occurred or may occur, and not the territory of the Member State in which the infringement has its results.

On that basis, the Advocate General suggested that in order to determine the law applicable to the claims formulated by Nintendo and falling within the scope of Regulation No. 6/2002, account should be taken of the place of active behaviour of the perpetrator. However, in the Nintendo case, there was a difficulty in determining the active behaviour in question insofar as the infringing activities took place in several Member States. Nevertheless, the Advocate General considered that the incident causing the infringement was a one-off and took place on the territory of only one Member State, namely France, because the products were manufactured there. He pointed out that if these products were not produced, the infringement would simply not have taken place because products would not be sold on the markets of individual Member States. On this basis, he suggested that French law should be governing law for the case.

Secondly, the Advocate General referred to the determination of the applicable law by means of Article 8 (2) of the Rome II Regulation. He considered that Article 89 (1) (d) of Regulation No. 6/ 2002 and Article 8 (2) of the Rome II Regulation should be interpreted in the same way.

We have serious doubts as to the reasoning of the Advocate General presented in his opinion, as he suggests the parallel application of both conflict-of-law rules, while it is obvious that the law applicable to all Nintendo's claims should be determined on the basis of Article 8 (2) of the Rome II Regulation only. Therefore, there should be no doubt that this is the only conflict-of-law rule that should be applied.

It is true that sanctions and orders, as requested in the main proceedings against the defendants and which are the subject of the third ques-

9 Coty Germany GmbH v. Parfümerie Akzente GmbH, Case C 230/16, Judgment of 6 December 2017, E.C.R 2017, (ECLI:EU:C:2017:941). 
tion, fall under the sanctions and orders provided for in Article 88(2) and Article 89(1)(d) of Regulation No. 6/2002, but these provisions do not regulate these sanctions and order in an autonomous way, but just refer to the legislation of the Member States, including their private international law provisions. Such provisions are, therefore, the conflict-of-law provisions of the Rome II Regulation (with the exception of Denmark, which is not bound by it). We are dealing here with a specific type of referring provisions in the Regulation No. 6/2002, and not with the true conflict-of-law rules.

It should be underlined that Regulation No. 6/2002 does not regulate the enforcement of non-contractual obligations resulting from the infringement of EU uniform IP laws. For this reason, the reservation provided for in Article 8(2) ("In the case of a non-contractual obligation arising from an infringement of a unitary Community intellectual property right, the law applicable shall, for any question that is not governed by the relevant Community instrument [highlighted: authors], be the law of the country in which the act of infringement was committed.") has a relatively narrow scope. It concerns only the existence and scope of the IP rights and not the claims for infringement.

At most, we can agree with the statement of the Advocate General that the provisions of Regulation No. 6/2002 provide a conflict-of-law rule $^{10}$. However, this is just a conflict-of-law rule of the second degree, locating only the relevant provisions of private international law, that ultimately determines the governing law for the case ${ }^{11}$. The content of the conflict-of-law rule therefore contains a reference structure (renvoi) to national regulations of private international law, while at the same time, these regulations refer to Rome II.

${ }^{10}$ E. Schaper, Choice-of-Law Rules in the EU - Special Issues with Respect to Community Rights - Infringement of Community Trade Marks and Applicable Law, [in:] J. Drexl, A. Kur (ed.), Intellectual Property and Private International Law: Heading for the Future, Oxford-Portland, Oregon: Hart Publishing, 2005, p. 202-205; T. Jehoram, C. Van Nispen, T. Huydecoper, European Trademark Law. Community Trademark Law and Harmonized National Trademark Law, Alpen aan den Rijn: Wolters Kluwer, 2010, p. 529-530.

11 A. Metzger, Community IP Rights \& Conflict of Laws - Community Trademark, Community Design, Community Patent - Applicable Law for Claims for Damages, [in:] J. Drexl, A. Kur (ed.), Intellectual Property and Private International Law: Heading for the Future, Oxford-Portland, Oregon: Hart Publishing, 2005, p. 217. 
The conflict-of-law rule of Regulation No. 6/2002 is flawed because although it contains connectivity with loci delicti commissi - it does not allow its effective use. This is because, by referring to the national private international law, it results in the need to use a national conflict-of-law rule, which, as a rule, is more or less precisely based on connecting factor locus protectionis. The territory of protection in the case of a uniform EU intellectual property right is the territory of the entire EU. Against the background of the erroneous considerations of the Advocate General, there is no doubt that it was appropriate to introduce a clear conflictof-law rule in Article 8(2) of the Rome II Regulation - a formula, which, in accordance with Article 24 of that Regulation, does not contain the renvoi problem (owing to its exclusion). In opinion of M. Illmer, even if it is assumed that Regulation No. 6/2002 contains true conflict-oflaw rules, their application in practice is excluded by Article 8(2) of the Regulation Rome $\mathrm{II}^{12}$.

Equally erroneous, although used in practice, is the application by the Advocate General of jurisdiction provisions, in a situation where conflictof-law and jurisdiction rules have different purposes. In particular, there is a risk of a too-wide interpretation of the connecting factor of the infringement place based on jurisdiction rules. The opinion of the Advocate General is a good illustration of the risk of misinterpretation of the conflict-of-law rules, both when it comes to determining their relationship with each other, and sometimes by uncritically making reference by analogy to judgments issued in the field of national jurisdiction. It is this element that is potentially the most dangerous for the practice because the current tendency in national jurisdiction points to a very flexible, mosaic interpretation of the connecting factor of the place of infringement in jurisdictional norms that allows the jurisdiction of courts of various EU Member States in the event of infringement of Community design right. Meanwhile, the use of the connecting factor of the place of infringement in conflict-of-law rules should in principle lead to the indication of one applicable law. At the same time, it cannot be forgotten that the conflict-of-law rule in Article 8(2) is a clarification

${ }_{12}$ M. Illmer, [in:] P. Hubner (ed.), Rome II Regulation. Pocket Commentary, München: Selier, 2011, p. 240. 
of the rule of lex loci protectionis, which obviously does not appear in the rules of jurisdiction.

As to the final conclusion of the Advocate General, the question arises as to how the French language version of Article 8(2) of the Rome II Regulation has contributed to this, when it refers to the law of the country in which "intellectual property rights have been infringed". Such wording makes it impossible to determine whether this concept requires active behaviour on the side of the perpetrator of the infringement in such a designated country, outside the place where the infringement causes effects. Other language versions of that provision, such as versions in Spanish, German, Italian, Lithuanian, Dutch, Portuguese, Slovenian, and Swedish, are more clear in this field, as they refer to the law of the country in which "the infringement was committed". The same applies to the English version, which refers to the law of the country, "in which the act of infringement was committed".

It is worth mentioning that this issue was discussed also by Advocate General Athelet in the opinion delivered on 5 September 2013 in case C-479/12 H. Gautzsch and his reasoning is in sharp contrast with the opinion advanced by AG Bot above. AG Wathelet rightly pointed out that: "It is clear from the very wording of that provision that the Union legislature did not leave the choice of law applicable to the properly seized court. On the contrary, the law applicable is always the law (or laws) of the Member State (or Member States) in which the infringing act (or acts) was (or were) committed. It is therefore never a question of applying the law of the Member State of the court seized by reason merely of its territorial jurisdiction. (cf. 100)" and concluded in cf 102 that such interpretation is not only shared by academic writers, but is also adopted in Article 8 of Regulation No 864/2007 on the law applicable to non-contractual obligations (cf. 102).

\section{THE POSITION OF THE COURT OF JUSTICE OF THE EUROPEAN UNION}

The CJEU in its judgment of 27 September 2017 correctly did not share the conclusions of the Advocate General's Opinion. In the third thesis of this judgment, this court ruled, that Article 8 (2) of the Rome II Regulation 
should be interpreted in a way that the "country in which the act of infringement was committed" refers to the country where the event giving rise to the damage occurred.

What is important, the CJEU has explicitly indicated that the applicable law should be determined in a uniform manner on the basis of Article 8 (2) of the Rome II Regulation. It was also emphasized that the connecting factor concerning the "country in which the act of infringement was committed" is different from the connecting factor provided for in Article 4 (1) of the Rome II Regulation - "the country in which the damage occurs" ${ }^{13}$. As a result, the term "country in which the act of infringement was committed" within the meaning of Article 8 (2) of the Rome II Regulation should be interpreted as referring to the country of the place where the act causing the damage occurred, i.e. the country in whose territory an infringement has been committed ${ }^{14}$.

The CJEU based its reasoning and interpretation on the uniform character of the Community design right and on the principle of the predictability of the decisions: "Secondly, unitary intellectual property rights are protected throughout the European Union and infringing acts may be carried out in several Member States, which therefore makes the determination of the substantive law applicable to questions not governed independently by the relevant Community instrument rather unpredictable." (cf. para 101).

We fully agree with CJEU's statement that the connecting factor provided for in Article 8(2) of the Rome II Regulation should be understood autonomously, in separation from the general rule of Article $4(1)$. Consequently, protection is ensured on the basis of a given national regulation based on the connection factor of the place of infringement, regardless of whether the damage occurred on this national territory. Article 8(2) of the Rome II Regulation correctly uses the connecting factor of the place of the infringement, not the place of damage, because

${ }^{13}$ T. Graziano, Das auf außervertragliche Schuldverhältnisse anzuwendende Recht nach Inkrafttreten der Rom II-Verordnung. The Law Applicable to Non-Contractual Obligations (Rome II Regulation), [The Law Applicable to Non-Contractual Obligations After the Entry Into Force of the Rome II Regulation. The Law Applicable to Non-Contractual Obligations (Rome II Regulation)], "Rabels Zeitschrift für ausländisches und internationales Privatrecht" 2009, vol. 73(1), pp. 13-25.

${ }^{14}$ H. Schack, The Law Applicable to (Unregistered) IP Rights After Rome II, "Ritsumeikan Law Review" 2009, vol. 26, pp. 129-144. 
the occurrence of damage is not a condition for the majority of claims resulting from the infringement of exclusive IP rights.

It must be assumed that the place of the infringement is the place of direct and substantial infringing into uniform EU intellectual property rights. This concept therefore does not include the indirect effects of the infringement that have occurred in another country.

In addition, it should be pointed out that the most important recitals of the judgment repeat the CJEU statement that where the same defendant is accused of various acts of infringement committed in various Member States, the correct approach for identifying the event giving rise to the damage is not to refer to each alleged act of infringement, but to make an overall assessment of that defendant's conduct in order to determine the place where the initial act of infringement at the origin of that conduct was committed or threatened by $\mathrm{it}^{15}$. The proposed interpretation allows the national court, in a relatively easy way, to determine the law by a single connecting factor related to the place where an infringement has been made or may be made the source of several acts carried out by the defendant.

In our opinion this conclusion is of fundamental importance, going beyond this particular case, because the CJEU clearly indicates the need to consolidate the applicable law in order to avoid the so-called mosaic approach that leads to particularly dangerous results in case of infringements of intellectual property rights as it involves forum shopping risks.

Equally useful are court remarks relating to the infringement of industrial property rights. These apply directly to the situation in which an economic operator is accused of offering for sale, without the consent of the holder of the rights conferred by the EU designs, via its website, goods allegedly infringing those rights, in a case of a site being accessible to consumers situated in Member States other than the country in which the infringer is established. The event giving rise to the damage is the conduct by which an operator offers for sale allegedly infringing goods, inter alia by placing an offer for sale on its website ${ }^{16}$. Accordingly, the place where the event giving rise to the damage occurred within the

\footnotetext{
15 Supra note 1, point 111.

16 Supra note 1, point 108.
} 
meaning of Article 8(2) of Regulation Rome II is the place where the process of putting the offer for sale online by that operator on its website was activated.

\section{FINAL REMARIS}

CJEU permits consolidation in the process of determining the applicable law, which consists in adopting that, in circumstances where the same defendant is accused of various acts of infringement committed in various Member States, the correct approach for identifying the event giving rise to the damage is not to refer to each alleged act of infringement, but to make an overall assessment of that defendant's conduct in order to determine the place where the initial act of infringement at the origin of that conduct was committed or threatened by it. This is the correct approach, in opposition to the national courts' tendency to use, for the needs of consolidation of applicable law, the connecting factors provided by Article 4 of the Rome II Regulation (e.g. the corrective rule in Article 4(3)).

Therefore, it is necessary in the process of determining the applicable law, to distinguish it from the rules for determining national jurisdiction (which involved guidance provided in this area by the CJEU so far). This also applies to the case when - at first glance - the same connecting factor (e.g. place of infringement of the law) was used in both the jurisdictional and the conflict-of-law provisions. The analyzed case concerns only specific Community design right (i.e. industrial design), but it must be borne in mind that, when it comes to applicable law (unlike national jurisdiction), the connecting factor is based on the locus protectionis criterium, that is the country of protection.

Taking all of the presented arguments into consideration, the CJEU ruling in the Nintendo v. BigBen case should be evaluated positively. On the other hand, the Advocate General's opinion is an example of how the conflict-of-law analysis should not be done - that conclusion is also useful. 